\title{
Fe-Si-AI 系アトマイズ微粉を用いた低コアロス圧粉磁芯
}

\author{
武本 聡* , 齊藤貴伸 ${ }^{*}$
}

\section{Fe-Si-Al low core loss compressed cores with atomized fine powders}

\author{
Satoshi Takemoto, and Takanobu Saito
}

\begin{abstract}
Synopsis
Compressed cores made with soft magnetic alloy powders are widely used for smoothing and boost choke coils of switching regulators and DC-DC converters. Low core loss is required to be high performance of these compressed cores. In this study effects of particle size and crystal grain size on core loss of compressed cores with Fe-Si-Al atomized powders were investigated. Particle size and crystal grain size of powders were changed by water-atomization and heat treatment conditions. Compressed cores were made with these powders and obtained following results.

(1) Eddy current loss decreased with decreasing of the particle size, and hysteresis loss decreased with increasing of the crystal grain size of powders; the compressed core with small particle size and large crystal size showed low core loss.

(2) The compressed core with heat-treated fine powder (mean diameter = about $10 \mu \mathrm{m}$ ) showed very low core loss (about $300 \mathrm{~kW} / \mathrm{m}^{3}$, at $B=0.1 T$ and $f=100 \mathrm{kHz}$ ).
\end{abstract}

\section{1. 緒 言}

近年 ,ノートパソコン ,デスクトップパソコンなどの OA 機器に用いられる部品において, 高機能化や小型化の要求 が高まっている．また，自動車においては直噴エンジン制 御や高輝度放電型のヘッドライトが普及し始めている。

これらの制御用電源にはスイッチング電源や DC-DC コ ンバーターが欠かせないものとなっている.圧粉磁芯は軟 磁性粉末に絶縁物を混合した後,例えばトロイダル状にプ レス成形したもので,これらの電源の平滑用チョークコイ ルや, 昇圧チョッパ用チョークコイルの磁芯として多用さ れている.

圧粉磁芯用軟磁性粉末は光の成分として主に $\mathrm{Fe}-\mathrm{Si}-\mathrm{Al}$ 系合金が用いられており，一般的にはインゴットを機械 的に粉砕した粉砕粉やアトマイズ粉を原料として用いる ことが多い．筆者らは前報 ${ }^{1), 22,3), 4)}$ でアトマイズ粉を用い た Fe-Si-Al 系圧粉磁芯について報告し,アトマイズ方法に より粉末粒子形状を変化させ, 圧粉磁芯の初透磁率, 直流
重畳特性 ,コアロスおよび抵抗率に及ぼすに影響について 明らかにしてきた .

本報告ではコアロスを低減させるために粉末粒径および 粉末粒内の結晶粒径に着目した. Fe-Si-Al 系アトマイズ粉 を用いて粉末粒径を変化させてコアロスを測定し, 粉末粒 径および金属組織的要因とコアロスの関係を明確にした .

\section{2 . 実験方法}

\section{1 実験に用いた原料粉末}

本報告では水アトマイズと改良型水アトマイズの 2 種類のアトマイズ法により原料粉末を作製した. 改良型 水アトマイズとは従来の水アトマイズの操業条件を制 御することにより粉末の形状をコントロールできる噴 霧法である . 成分は軟磁気特性が最も良好とされている $\mathrm{Fe}-9.5 \mathrm{mass} \% \mathrm{Si}-5.5 \mathrm{mass} \% \mathrm{Al}$ に近いものを用い, 実験に用 いた原料粉末の成分を Table 1 に示す. また，走査型電子 顕微鏡による観察写真を Fig.1 に示す . 粉末の外観はいず れも類似しており，楕円体に近い形状をしている． 
Table 1. Chemical compositions of experimented Fe-Si-Al alloy powders.

\begin{tabular}{c|c|c|c}
\hline \multicolumn{1}{l}{} & \multicolumn{2}{r}{ (mass \%) } \\
\hline $\begin{array}{c}\text { Modified-water } \\
\text { atomization }\end{array}$ & 9.54 & 5.50 & 0.04 \\
\hline $\begin{array}{c}\text { High pressure } \\
\text { water atomization }\end{array}$ & 9.50 & 5.56 & 0.04 \\
\hline
\end{tabular}

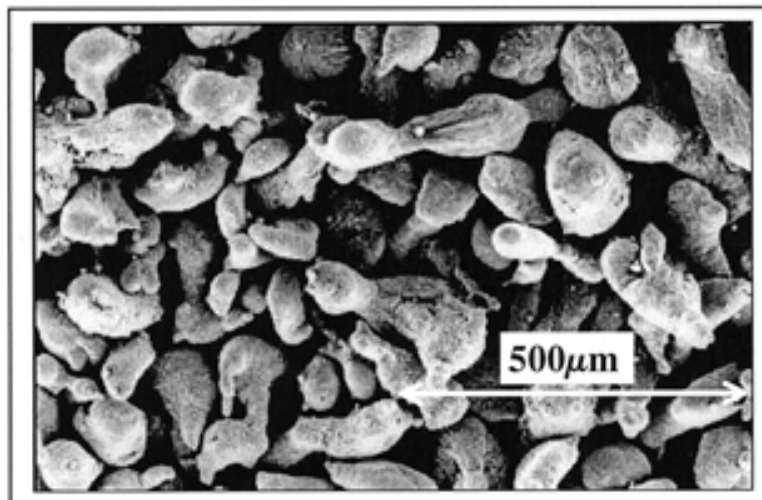

Modified-water atomization(-100mesh)

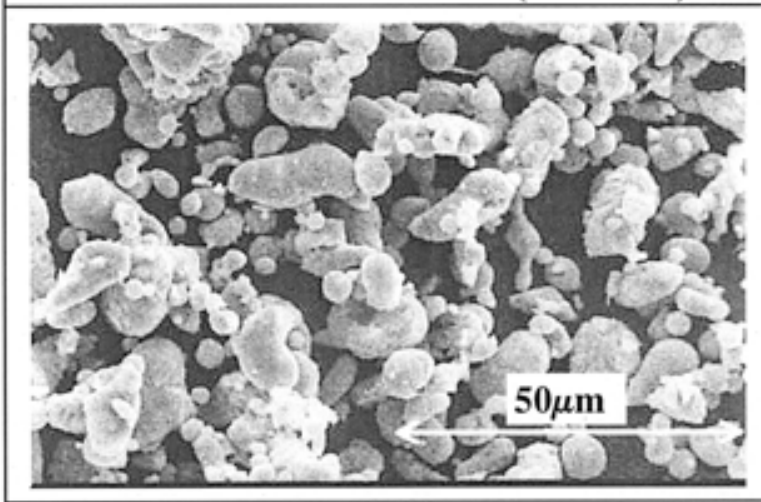

High pressure water atomization $\left(\mathrm{D}_{50}=11 \mu \mathrm{m}\right)$

Fig.1. SEM photographs of modified-water atomized and high pressure water atomized powders.

アトマイズ時の歪を減少させる目的で, 不活性ガス雾囲 気などで粉末熱処理をする場合が多い，本報告では，結晶 粒径をコントロールすることを目的とし, 水素雾囲気中で 1073K〜1223Kで 1 時間保持した .

\section{2 粉末粒子径別の分級}

平均粒径 $\left(\mathrm{D}_{50}\right)$ が約 $20 \mu \mathrm{m}$ 以上の粉末は改良型水アト マイズ粉を用い, 原料粉末を粒子径別に, $-100 /+140$ メッ シュ $(-150 /+106 \mu \mathrm{m}),-200 /+235$ メッシュ $(-75 /+63 \mu \mathrm{m})$, $-235 /+330$ メッシュ $(-63 /+45 \mu \mathrm{m}), 635$ メッシュ $(-20 \mu \mathrm{m})$ 以下のように篩い分けした .一方、平均粒径が $20 \mu \mathrm{m}$ 以下の粉末は、高圧の水を用いてアトマイズを行い 所定の粒径に調整した。(以下この粉末を高圧水アトマイ ズ微粉と呼ぶ）。

\section{3 圧粉磁芯の作製}

まず,原料粉末にバインダーおよび粒子間の電気的絶縁 のためにシリコーン樹脂 (東レ・ダウコーニング・シリ コーン社製 SR-2400) を1mass％添加し混練した . 恒温槽 で乾燥後, 潤滑剂としてへガネス社製ケノルーブを 0.5 mass \% 混合してプレス成形した . 成形は室温で 1960MPa の圧力で戍圧プレス機を用いて行なった . 圧粉 磁芯のサイズは外径 $28 \mathrm{~mm}$ 内径 $20 \mathrm{~mm}$ 高さ約 $5 \mathrm{~mm}$ のトロ イダル状とした . 成形された圧粉磁芯を $\mathrm{Ar}$ 雰囲気中で熱 処理した . 磁芯の熱処理は 748K で保持時間は 3.6ks（1 時 間)とした。

\section{4 磁気特性評価}

磁気特性としてコアロスを測定した · 交流 B H アナラ イザ (岩崎通信機製 SY-8232) を用いて，励磁磁束密度を $0.1 \mathrm{~T}$ と一定にし、周波数を $100 \mathrm{kHz}$ まで変化させた .

\section{3 .結果および考察}

\section{1 コアロスに及ぼす粉末粒径の影響}

各粒度に分級した粉末を用いて圧粉磁芯を作製し，磁気 特性の粉末粒径依存性を調査した.粉末熱処理温度はすべ て 1223K で一定とした . Fig.2 に励磁磁束密度 0.1T , 周波 数 $100 \mathrm{kHz}$ におけるコアロスにおよぼす粉末の平均粒径 $\left(\mathrm{D}_{50}\right)$ の影響を示す . 図中で白抜きの改良型水アトマイズ 粉において, 平均粒径が咸少するにしたがって,コアロス は低減している .図中で黑塗りの高圧水アトマイズ微粉 (平 均粒径 $\left.\left(\mathrm{D}_{50}\right)=7 \sim 11 \mu \mathrm{m}\right)$ のコアロスは $220 \sim 270 \mathrm{~kW} / \mathrm{m}^{3}$ と非常に低減している.しかしながら, 弚の值は改良型水 アトマイズ粉を分級して得られた微粉のコアロスより大 きくなっている .この原因を明らかにするため, 渦電流損 およびヒステリシス損に及ぼす粉末粒径と結晶粒径の影 響について調査し考察を行った 。

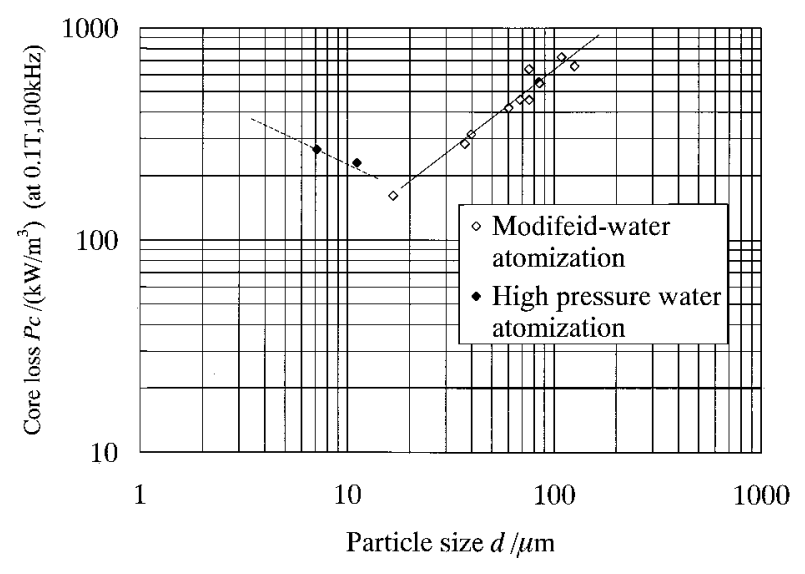

Fig.2. Influence of particle size on core loss. 


\section{2 渦電流損に及ぼす粉末粒径の影響}

コアロス Pc は通常，ヒステリシス損 $\mathrm{Ph}$ と渦電流損 $\mathrm{Pe}$ に分離して考察される.

$\mathrm{Pc}$ を $\mathrm{Ph}$ と Pe に分離する方法は以下の通りとした . (1) 式，(2) 式に示すように，各周波数で得られたコアロスを 周波数で除し, Pc/f の周波数依存性を得た .この Pc/f を $0 \mathrm{~Hz}$ (直流)にまで外挿した值を 1 周期当たりのヒステリ シス損失係数 $(\mathrm{Kh}=\mathrm{Ph} / \mathrm{f})$ とし，ここから $100 \mathrm{kHz}$ でのヒ シテリシス損失 $\mathrm{Ph}$ を計算した . 渦電流損失 $\mathrm{Pe}$ は Pc から $\mathrm{Ph}$ を差し引いた残りと考えた .

$$
\begin{aligned}
& \mathrm{Pc}=\mathrm{Ph}+\mathrm{Pe}=\mathrm{Kh} \cdot \mathrm{f}+\mathrm{Ke} \cdot \mathrm{f}^{\mathrm{n}} \\
& \mathrm{Pc} / \mathrm{f}=\mathrm{Kh}+\mathrm{Ke} \cdot \mathrm{f}^{\mathrm{n}-1}
\end{aligned}
$$

Fig.3 に渦電流損に及ぼす粉末粒径の影響についての両 対数グラフを示す.粉末粒径が減少するに従い, 渦電流損 も減少している．渦電流損の值は高圧水アトマイズ微粉， 改良型水アトマイズ粉によらず粉末粒径に依存している ことが分かる。

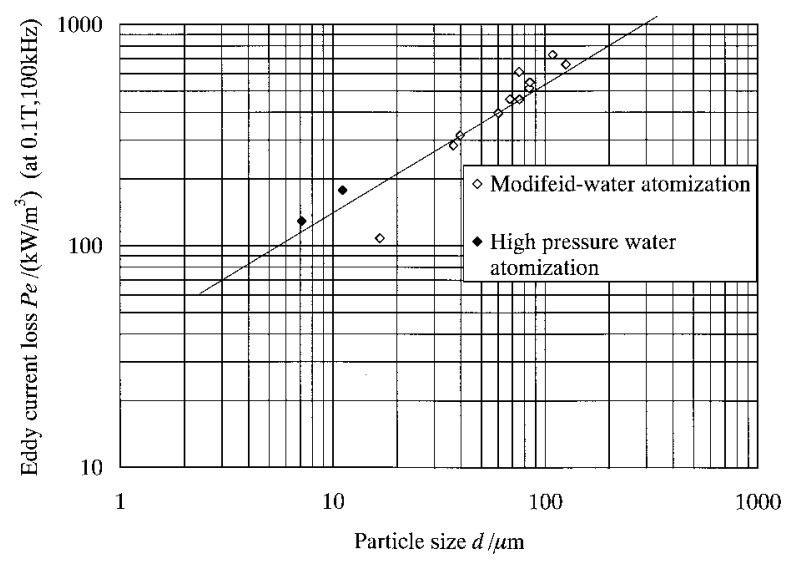

Fig.3. Influence of particle size on eddy current loss.

また一般に，球状の軟磁性体が独立して存在し，表皮深 さか球の直径よりも十分深いとき, 渦電流損は次式で表現 される5) .

$\mathrm{Pe}=(\pi \cdot \mathrm{Bm} \cdot \mathrm{d} \cdot \mathrm{f})^{2} /(20 \rho \cdot \eta)$

ここで,

$\rho:$ 電気抵抗率 $[\Omega \mathrm{m}] \mathrm{f}$ : 周波数 $[\mathrm{Hz}] \mathrm{Pe}:$ 渦電流損 $\left[\mathrm{W} / \mathrm{m}^{3}\right]$ $\mathrm{Bm}$ : 励磁磁束密度 $[\mathrm{T}] \mathrm{d}$ : 粉末の直径 $[\mathrm{m}] \eta$ ：磁性体の充 填率である.実測值と計算值を比較するために， $\mathrm{Bm}=0.1[\mathrm{~T}], \mathrm{f}=100[\mathrm{kHz}]$ ，また $\rho=80 \times 10^{-8}[\Omega \mathrm{m}] \quad(\mathrm{Fe}-\mathrm{Si}-\mathrm{Al}$

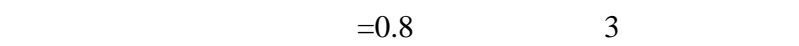
て , 渦電流損 Pe の粉末粒子径 $\mathrm{d}$ の依存性を計算した結果 をFig.4に示す .

計算值は (3) 式からも分かるように粉末粒径 $\mathrm{d}$ の 2 乗 に比例するのに対し，実測では $\mathrm{d}$ に比例しており，粉末粒

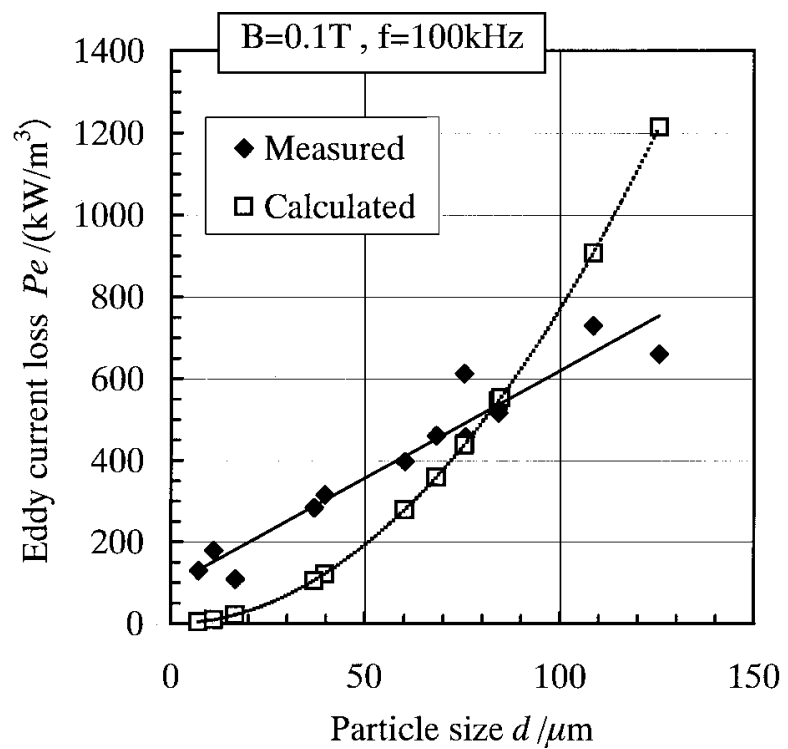

Fig.4. Comparison of measured eddy current loss and calculated eddy current loss.

径に対する依存性が異なっている．実測値と計算值は大雑 把には一致するが,粒径の依存性までは一致しない結果と なった .この不一致の原因として, 渦電流損に及ぼす磁区 構造の影響や 6) 表皮深さの影響などが存在するためと考 えられ，さらなる理論的検討が必要である．

\section{3 ヒステリシス損に及ぼす粉末粒径の 影響}

Fig.5 にヒステリシス損に及ぼす粉末粒径の影響につい て示す.渦電流損とは逆に, 粉末粒径か減少するに従いヒ ステリシス損は増加しており，この傾向はアトマイズ方法 によらず同樣である.高圧水アトマイズ微粉のヒステリシ ス損は改良型水アトマイズ粉よりもかなり大きな值と なっている.圧粉磁芯においても, 酸素含有量が高いほど 保磁力が大きくなる ${ }^{1)}$ と報告され，コアロスを低下させ

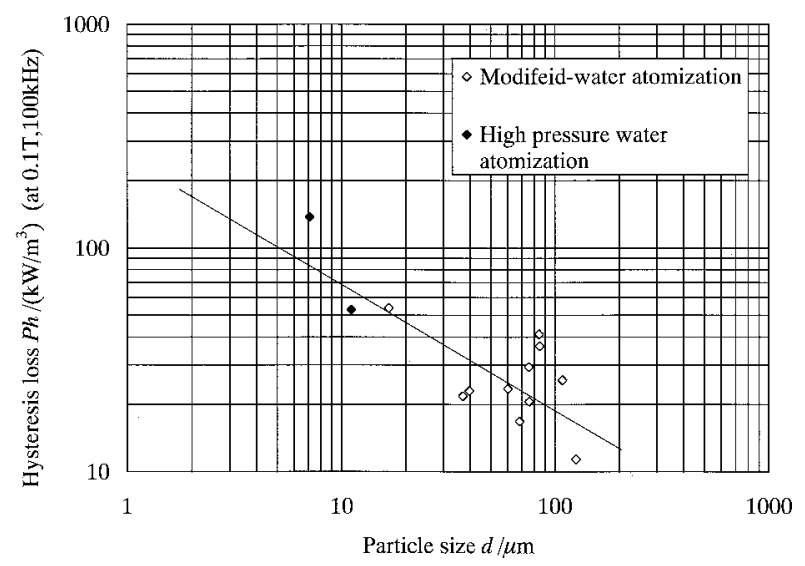

Fig.5. Influence of particle size on hysteresis loss. 
るためには低酸素とすることが有効であると述べられて いる。しかし，本報告で用いた高圧水アトマイズ微粉，改 良型水アトマイズ粉末の酸素量はともに $0.04 \mathrm{mass} \%$ と低 く，双方の值に差は見られない，このため，本報告におい てヒステリシス損に及ぼす酸素量の影響はほとんどなく， 粉末粒内の結晶粒径の影響が考えられるため次節にて検 討を行った。

\section{4 ヒステリシス損に及ぼす結晶粒径の 影響}

ヒステリシス損に及ぼす粉末粒内の結晶粒径の影響を 調べるため, 平均粒径が $11 \mu \mathrm{m}$ の高圧水アトマイズ微粉 を用いて粉末熱処理温度を $1073 \mathrm{~K} \sim 1273 \mathrm{~K}$ の範囲で変化 させた試料を作製した . Fig.6ににヒステリシス損に及ぼす 粉末熱処理温度の影響について示す。お，图中で約 300K の点は粉末熱処理を実施していない場合である.粉末の熱 処理温度が上昇するに従ってヒステリシス損は急激に減 少している。

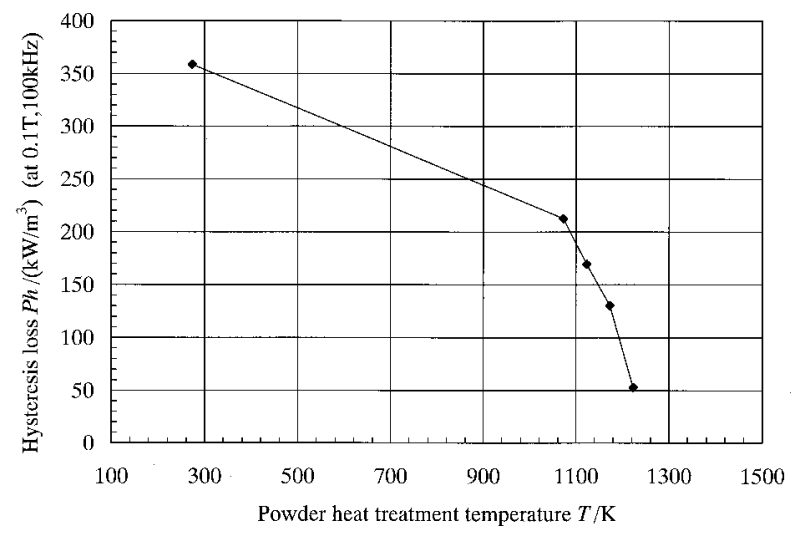

Fig.6. Influence of powder heat treatment temperature on hysteresis loss.

Fig.7 に高圧水アトマイズ微粉で粉末熱処理温度を变化 させた圧粉磁芯の断面の顕微鏡組織写真を示す.粉末熱処 理温度が上昇するにつれて, 結晶粒径は増加する傾向が見 られた . 顕微鏡組織写真より粉末粒内の結晶粒径を測定 し、結晶粒径とヒステリシス損の関係をプロットした図を Fig.8 に示す. 高圧水アトマイズ微粉も改良型水アトマイ ズ粉の場合も結晶粒径が大きくなるに従い,ヒステリシス 損は減少する傾向が見られる.同図によると粉末のアトマ イズ方法や粉末の粒径に因らず,ヒステリシス損は結晶粒 径により大きく左右されると考えられる .

Fig.9に改良型水アトマイズ粉と高圧水アトマイズ微粉を 用いた圧粉磁芯の断面顕微鏡組織写真を示す. 高圧水ア卜 マイズ微粉を用いた場合，結晶粒径か細かくなっている．

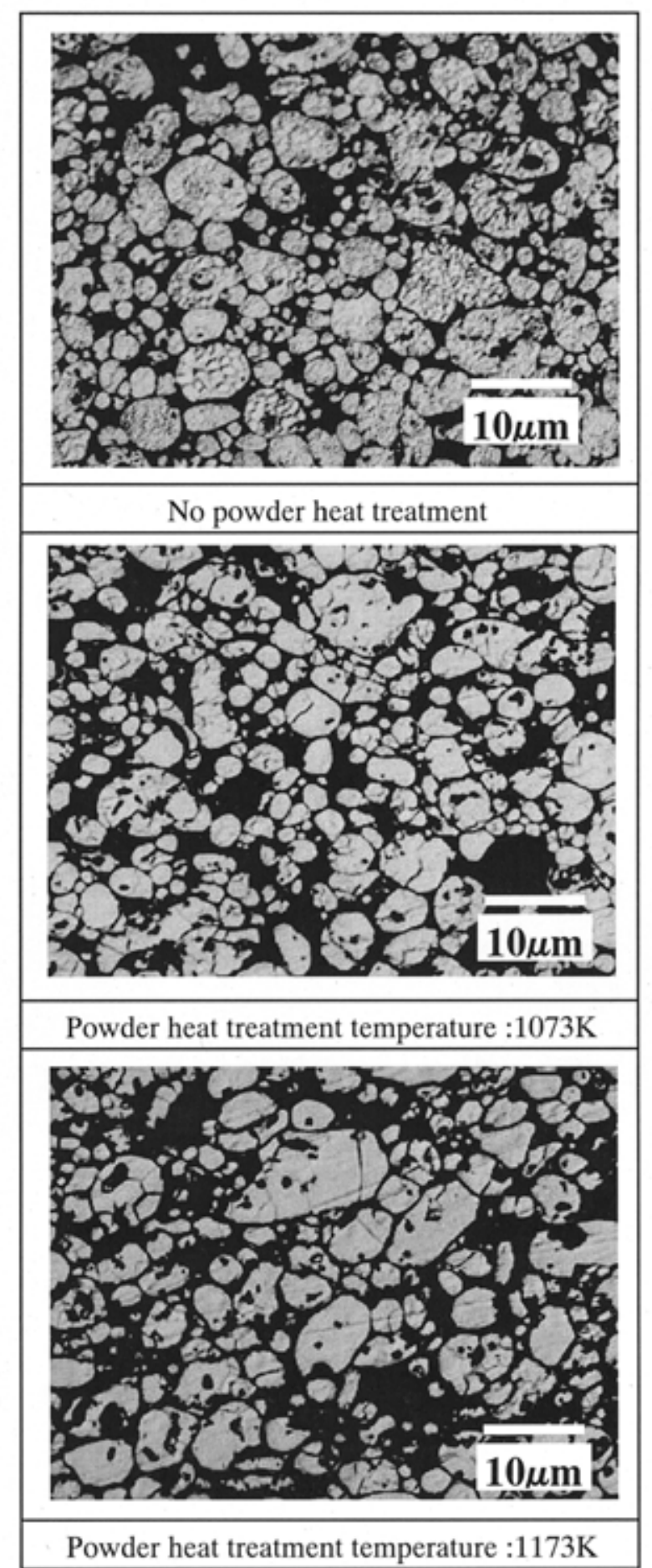

Fig.7. Influence of powder heat treatment temperature on microstructure of crystal grain of high pressure-water atomized powder core.

Fig.5 において, 高圧水アトマイズ微粉のヒステリシス 損か改良型水アトマイズ粉の場合よりも大きい原因は, 結 晶粒径が高圧水アトマイズ微粉の方が微細になっている からと考えられる . 


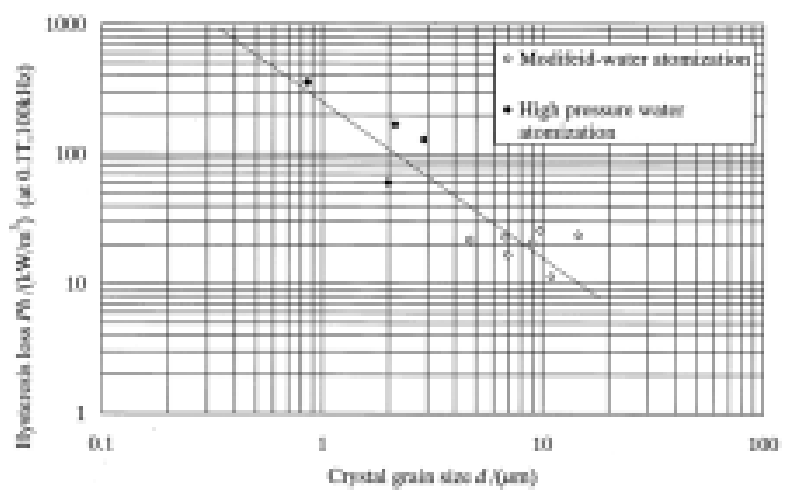

Fig.8. Influence of crystal grain size of powder on hysteresis loss.

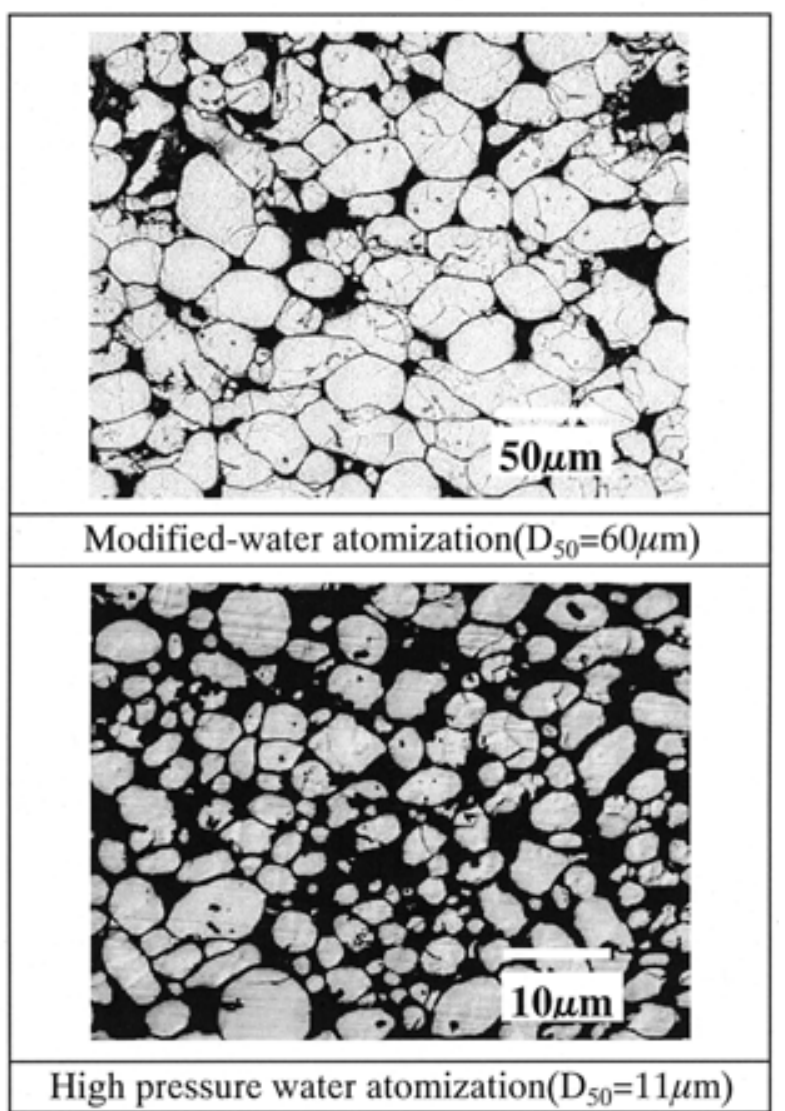

Fig.9. Microstructure of crystal grain of modified-water atomized and high pressure water atomized powder cores. (Powder heat treatment temperature $=1223 \mathrm{~K}$ )

今後の方針として更なるコアロス低減には ,微粉を用い て噴霧条件や粉末の熱処理条件を適正化することにより 結晶粒径を粗大化させヒステリシス損を低減することが 必要である。

\section{4 ．結 論}

本報告では高圧水アトマイズ法, 改良型水アトマイズ法 によって得られた Fe-Si-Al系合金粉末を用いて粉末粒径を 変化させて圧粉磁芯を作製し,コアロスおよび粉末粒内の 結晶粒径を評価した．乥こで以下の結論を得た．

(1) 渦電流損はアトマイズ法によらず粉末粒径で整理で き, 粉末粒径がが小さくなるに従い減少する .

(2) 渦電流損は一般に言われているような粉末粒径の 2 乗 に比例する関係は認められず、表皮深さや磁区構造の影響 を考慮する必要があると考えられる。

(3) ヒステリシス損はアトマイズ法によらず粉末粒内の結 晶粒径でほぼ一義的に整理でき, 結晶粒径が大きくなるに 従い減少する.

(4) 粉末粒径 $\left(D_{50}\right)$ が約 $10 \mu \mathrm{m}$ の高圧水アトマイズ微粉 を用いた場合, 励磁磁束密度 $0.1 \mathrm{~T}$, 周波数 $100 \mathrm{kHz}$ でのコ アロスの值は約 $300 \mathrm{~kW} / \mathrm{m}^{3}$ と非常に低い値を示した。

\section{謝辞}

本研究を遂行するに当たり，一連の実験の実施に協力し ていただいた大同特殊鋼株式会社技術開発研究所管理室 試作第三係の坂元親男氏に感謝します.また最後になりま したが,原料粉として各種アトマイズ粉を提供して頂きま した大同特殊鋼株式会社粉末事業部の方々にお礼を申し 上げます．

\section{(文 献)}

1)齊藤貴伸, 矢萩慎一郎: 電気製鋼 ,69(1998), 181.

2)齊藤貴伸, 武本聡: 電気製鋼 ,71(2000), 287.

3)武本聡, 齊藤貴伸: 電気製鋼 ,73(2002), 229.

4)S.Takemoto and T.Saito: Proceedings of the $\mathrm{PM}^{2}$ TEC 2002 WORLD CONGRESS.,Part 8-Material Properties(2002)

5)R.M.Bozorth:Ferromagnetism , D.Van Nostrand Company, $\operatorname{Inc}(1951)$, p.769

6)榊陽，今城慎一: 電気学会論文集A, 101(1981), 575 